\title{
English-Arabic Code-Switching of the Arabic Language Speakers in Instant Messaging: Motivations and Structure
}

\author{
Asmaa Ahmed Hassan Ahmed*
}

\section{Introduction}

Modern technology has been invading the world, and it is widespread in all fields of life. One of the most prominent fields is Telecommunication, especially with the invention of smart phones and their advanced operating systems such as Android and IPhone Operating System (iOS).They provide useful and innovative applications in all areas of life. One of the most popular applications is "WhatsApp". It is an instant messaging application that uses the internet to send text messages, documents, images, voice notes, and videos to other users who are using it through their cell phone numbers. According to Chowdhry (2016), "In April 2013, WhatsApp reached 800 million active users, and by February 2016, it had grown to one billion". He also stated that "700 million photos and 100 million videos were being shared daily and the messaging system was hardly more than 10 billion messages each day". As a result, it cannot be denied that instant messaging is a phenomenon to the extent that 'WhatsApp', according to the Macmillan Dictionary is now a verb which means 'to communicate with somebody using the social media app, WhatsApp' as in the sentence "I will WhatsApp you". Thus, a new kind of language seems to appear among users, and the role of researchers is to investigate this area to show how technology affects languages.

In Egypt, it can be noted that various topics are worth discussing when it comes to language; some of these areas are within the Arabic language due to its being a diglossic language that entails two different varieties: high and low, namely Egyptian Colloquial Arabic (ECA) and Modern Standard Arabic (MSA). Another salient issue is the switching between English and Arabic whether in written or spoken forms. Such areas are very interesting and motivating to investigate and research. The next section will shed more light on codeswitching.

\footnotetext{
* English Demonstrator in Faculty of Business Administration, Economics and Political Science, The British University in Egypt (BUE).

Cairo Studies in English - 2019(2): https://cse.journals.ekb.eg/
} 


\subsection{Code-Switching}

In many situations, a speaker may shift from one code to another whether intentionally or unintentionally. This shift can be from one language to another, one dialect to another, or from one style to another due to many different reasons (Sharaf Eldin, 2014, 79). Code-Switching is defined as "the juxtaposition within the same speech exchange of speech belonging to two different grammatical systems or subsystems". It is shifting from one language to another within the same utterance and/or speech event (Gumperz, 1982, 19). According to Samhan $(2017,111)$, code-switching is a conversational strategy used to establish, cross, or destroy group boundaries; to create, evoke, or change interpersonal relation with their rights and obligations. Another approach in defining code-switching was introduced by Meyerhoff in her book Introducing Sociolinguistics. According to Meyerhoff $(2006,116)$, code-switching in its most specific sense is the alternation between varieties or codes across sentences or clause boundaries.

There are various types of code switching; Gumperz $(1982,20)$ classifies code-switching into situational switching and metaphorical switching. Situational switching refers to the shift between two different codes in two different situations while metaphorical switching refers to the shifting due to the topic. Thus, the former highlights the role of the situation in determining the speaker's choice of language while the later highlights the role of the topic. Moreover, Myers-Scotton $(1993,9)$ proposes that there are two types of code switching: inter-sentential switching, which is between sentences from one language to another, and intra-sentential, which occurs within the same sentence.

When bilingual speakers switch between two languages, there might be motivations and reasons (Gal, 1988, 248). Bassiouney $(2009,29)$ explained that the many reasons that make bilinguals switch codes include filling the "lexical gaps". In other words, if they do not know a specific word in one of the languages, they choose to use it in the other one. According to Wei:

Sociolinguists who have studied code-switching drew attention to extra linguistic factors such as topic, setting, relationships between participants, community norms and values, and societal, political and ideological developments influencing speaker's choice of language in conversation. $(1998,156)$

Moreover, Grosjean $(1982,12)$ suggests that code-switching can occur for many reasons such as the speaker's inability to find an appropriate translation for the 
word in the language being used, or the reasons can depend on the interlocutors, situations, messages, attitudes, and emotions. Moreover, Muysken $(2000,10)$ asserts that another reason may be quoting someone (and as a result emphasizing one's group identity) or specifying the addressee. Furthermore, Sharaf Eldin $(2014,80)$ suggests that people switch codes for five reasons: to show solidarity, to express certain feelings or attitudes such as happiness, anger, or excitement, to reflect the speaker's status, to persuade the audience, or to discuss a certain topic.

As for English-Arabic code-switching, Alhazmi (2016, 185), asserts that code-switching between English and Arabic is possible at different grammatical levels and different patterns which are related to the typological characteristics of the pairs involved in code-switching. Moreover, code-switching can occur in four different categories which are extra-sentential switching, inter-sentential switching, intra-sentential, and intra-word switching. Alhazmi $(2016,186)$ adds that there are also code-switching patterns which can be single words or short phrasal or sentential constructions.

Concerning the structure of the code-switching sentences, Myers-Scotton $(1993,25)$ asserts that when two languages are used by a bilingual, there is a dominant language used, which is given the term "Matrix language ML". The ML is defined by the use of system morphemes that include determiners, inflections, pronouns, intensifier adverbs. The other language is called "embedded Language EL" which is defined by content morphemes that include nouns, verbs and adjectives (Myers-Scotton, 1993, 25-29).

\subsection{Audience Design}

The Audience Design Theory is derived from the Accommodation Theory developed by Giles and Powesland (1975). They acknowledge that "the accommodation model hypothesizes that speakers accommodate their speech style to their addressee in order to win approval" (Giles \& Powesland 1975, 292). Giles and Powesland $(1975,290-299)$ highlight a number of factors that may influence the speaker's style which are the topic, the setting and the level of attention paid to the speech. Speakers adjust/converge their style in order to gain the approval of the listener and build a rapport. Additionally, speakers adopt the same style that is close to the interlocutor's pattern of speech.

In 1984, Bell introduced the Audience Design Theory which is built upon the Accommodation Theory. He proposed that speakers design their speech based on what they assume their hearers know or believe (Bell, 1984, 10). In other words, speakers design their style in response to their audience. They shift to the 
interlocutor's own style, and this is based on the addressee's interests, backgrounds, and style (Dahl 2009, 18). "Speakers design their style primarily for and in response to their audience" (Bell 1991, 13).Bell's Audience Design Theory (1984) is more efficient than Giles and Powesland's (1975) Accommodation Theory as it does not only shed light on the speaker's response to the audience, but it also provides a very accurate classification of the types of the addressees/audiences. According to Bell $(1984,15)$, there are four types of audience that are classified according to whether they are addressed or known by the speaker. The one that comes in the first place is the addressee, who is known and directly addressed by the speaker. The addressee is the most influential co-conversant due to being the most salient, known, ratified and addressed (Dahl 2009, 19). Not only this, but Dahl also argues that the addressees have a greater effect on the speakers than their own self-monitoring $(2009,19)$. Later, Bell introduced the second level of audience whom he called "auditor" $(1984,22)$. Auditors are present in the conversation but not directly addressed. Dahl $(2009,19)$ adds that auditors are both known and ratified but not addressed. For more illustration, in a class, when the teacher is addressing a specific student, he/she is the addressee, and the rest of the class students are the auditors. In addition, Bell drew on Goffman's $(1981,130)$ reception formats to define audience's role and predicts that speakers primarily orient their styles to suit their addressed audiences followed by other types of audiences that may not be addressed. In other words, speakers take into consideration the characteristics, beliefs, backgrounds, and the interests of the audience; and as a result, they shift their style either to win their approval and / or grab their attention (Bell, 1991, 13-14).

Moreover, Goffman $(1981,133)$ and Bell $(1984,27)$ acknowledge two other types of audiences: first, the over-hearers or the bystanders whose presence is noticed by the speaker, but they do not take part in the conversation. Second, there is the "third party" whose presence is unknown. They are called the eavesdroppers, and although they are neither addressed nor engaged in the conversation, the over-hearer and/ or the eavesdropper may affect the style of the speaker (Goffman, 1981, 138).

It is worth mentioning that Bell $(1984,20)$ proposes that there are nonpersonal factors that can influence the style-shift, which are the setting and the topic. According to Bell $(1984,21)$ as cited in Dahl $(2009,20)$, the given topic or settings provoke speakers to style-shift and trigger a switch from one language to another and even from one dialect to another. For example, a group of students may code switch their speech into English when they talk about their English 
language course. However, Androutsopoulos $(2014,63)$ points out that the topic is very influential on language styles but to a lesser degree than the audience.

Androutsopoulos $(2014,64)$ also remarks that Bell (1984) distinguishes between two kinds of styles adopted by speakers: responsive style and initiative style. In responsive style, "the speaker converges to expectations by the audience", whereas initiative style "diverges from audience's expectations and draws instead on a language style associated with an absent third part (a referee, hence a referee deign)" (25).

Finally, no better quote can serve to summarize the main principles of the Audience Design Theory as Bell's quote:

In audience design, speakers accommodate primarily to their addressee. Third persons - auditors and over hearers - affect style to a lesser but regular degree. Audience design also accounts for bilingual or bidialectal code choices. Non-audience factors like topic and setting derive their effect by association with addressee types. $(1984,164)$

\subsection{Matrix Language Frame (MLF)}

According to Myers-Scotton $(1993,29)$, the MLF determines the morphosyntactic structure for the code-switched sentences. Moreover, it is a theory that attempts to identify the constraints on the process of code switching by hypothesizing that there is a base language which is the matrix language (ML) and another borrowed language which is the embedded language (EL). Due to its major contribution in the area of code-switching research, the Matrix Language theory has been discussed by several researchers. Chun $(2001,5)$ notes that there is "a frequency criterion" proposed by Myers-Scotton (1993) in order to identify ML, which means that the number of the morphemes of the participating languages determines the ML. The more frequent the ML in the code-switched sentences, the easier it is in determining the ML.

Later, Wakasa (2004), Macswan (2005), and Bassiouny (2009) proposed a more precise model that applies a structural criterion instead of applying the frequency based one; it proposes that the distinction between the ML and the EL is determined on the basis of the types of the morphemes (content morpheme or system morpheme). Malik $(2016,2106)$ explains that content morphemes are those that either assign or receive a thematic role, while system morphemes neither assign nor receive a thematic role. To illustrate, nouns, verbs, and adjectives are prototypical thematic role receivers while prepositions lack this ability (Wasaka, 2004, 7-10). Therefore, nouns, verbs, and adjectives are content 
morphemes, while functional and inflectional morphemes such as determiners and plural markers are system morphemes. Bassiouny $(2009,38)$ adds that the Matrix language is the language that contains the system morphemes such as determiners, prepositions, pronouns, negative markers, and the embedded language is the language that contains the content morphemes such as nouns, verbs and adjectives. Macswan $(2005,38)$, highlights a second feature that differentiates between the content morphemes and the system morphemes which is the "quantification" feature. This feature "quantifies individuals from other variables", such as quantifiers (e.g., all, any, some), determiner (e.g., the, a, an), possessive adjectives (e.g., my, your, his) and tense markers.

Additionally, Malik (2016), who conducted empirical research to evaluate the adequacy of the MLF in predicting recurring switching patterns between Urdu and English in a corpus of 1767 sentences, highlights that MLF is not only useful for analyzing the structure of code-switching sentences but also for predicting code switching patterns found across different language pairs.

\subsection{Objectives}

Although many studies have focused on code-switching in speech, little work has been done on the written forms. Additionally, people tend to be more conscious while writing, so this paper aims to investigate the reasons behind English/Arabic code-switching in written instant messaging within the frame work of Bell's theory of Audience Design that will be thoroughly presented in the methodology section. The paper also seeks to answer the following questions:

1- In the light of Audience Design Theory, what are the reasons and motivations behind switching codes while writing?

2- According to the Matrix Language Frame, which language is more frequent than the other in the English-Arabic code-switching sentences written by the Arabic speakers?

\section{Material and Methodology}

\subsection{Data Selection}

The conversational data for this study stem from naturally produced one-toone written conversations on WhatsApp. These conversations were between me, the researcher, the addressee, and several speakers. The idea of the paper came after the conversations took place; this means that neither the addressee nor the speakers knew that their conversations will be analyzed, so the data is spontaneous and unconstrained. Additionally, this prevented the fact that the 
participation of the researcher would skew the results. In fact, Milroy $(1987,79)$ stresses that it is acceptable to have researchers as participants as long as they do not control the flow of the conversations. Thus, it can be claimed that being the addressee in all the conversations did not have any noticeable effect on the speakers' code-switching behavior. It is also worth mentioning that none of them included private information or private topics. Moreover, the researcher asked for the permission of the speakers to use their sentences for analysis.

\subsection{Participants}

The participants, whose code-switching behavior is examined, are all native Arabic speakers. The ten speakers have completed their college education; however, they neither share the same educational background nor have the same occupations. The topics being discussed in the conversations were different, and each topic along with the speaker's educational background information will be mentioned in the data analysis section.

\section{Data Analysis}

Eighteen sentences by ten different speakers were analyzed using the tool of Matrix Language Frame (MLF) adopted by Myers-Scotton in (1993); moreover, the analysis is done under the framework of Bell's Audience Design Theory (1984). The data were analyzed using Myers-Scotton's model of a matrix language (1993). As for knowing the reasons and motivations, the data of this research were analyzed within the frame work of the Audience Design Theory in an attempt to know why the speakers chose to code-switch.

Analysis was conducted on a number of code-switching sentences. The sentences being analyzed are extracted from conversations between me (the researcher) and the speakers. Although I was writing in Arabic in all the conversations, the speaker chose to respond using Arabic-English code switching. This shows that the researcher did not control or direct the codeswitching behavior of the speakers. Moreover, in most of the conversations, the sentences being analyzed were responses to questions asked by me.

The sentences are written using the Transliteration Scheme for Non-Roman Scripts which is approved by the Library of Congress and the American Library Association. (See the appendix). This scheme is previously used by Bassiouney, (2009) in her book Arabic Sociolinguistics. The actual utterances said by the speaker in all the chats were in Arabic, so they are written first, and then they are followed by their transliteration and its translation. This is to address both Native Arabic and English readers. 


\section{Speaker (1)}

Speaker (1) is a graduate of the Faculty of Commerce, Arabic Section, and she received her education in Arabic schools. She is working as a teacher in a nursery. The topic being discussed was about a job interview.

$$
\begin{aligned}
& \text { 1) Me: inty fì il-shoghl? } \\
& \text { "Are you at work?" } \\
& \text { Speaker(1): lả, ảna mesh fì il-work } \\
& \text { Noun, Pr neg Prep-det noun } \\
& \text { "No, I am not at work" }
\end{aligned}
$$

In sentence no. (1), according to the ML hypothesis, the Matrix language (ML) is Arabic due to the occurrence of the system morphemes, negative marker, preposition and determiner) and the embedded language (EL) is English due to the occurrence of the content morpheme (noun).

2) Me: ha,īh īlakhbar?

ها إيه الأخبار? "What's the news?"

$$
\begin{aligned}
& \text { Speaker (1): 'mlt interview imbareh } \\
& 1 \text { sg-verb noun noun }
\end{aligned}
$$

In this sentence, the morphosyntactic structure belongs to the Arabic language as the speaker followed the sentence structure of the Arabic language except for replacing one word in English (content morpheme). Also, in following the frequency criterion in the MLF, it can be concluded that the ML is Arabic and the EL is English.

3) Me: we mltyīhba'd keda?

"What did you do afterwards?"

$$
\begin{array}{cc}
\text { Speaker (1): roht } & \text { il-nursery } \\
1 \text { sg-f (verb) } & \operatorname{det} \text { noun } \\
\text { "I went to the nursery" }
\end{array}
$$


In sentence no. (3), the ML is Arabic due to the occurrence of system morpheme (determiner " 1 l") and the EL is English due to the occurrence of content morpheme (noun).Thus, in the three sentences provided from this conversation, it is clear that speaker (1) chose to switch between Arabic and English utilizing Arabic as the ML and English as the EL. As for the reasons that motivated the addressee to code switch between English and Arabic, it can be argued that the words "interview" and "nursery" are loanwords used for lack of Arabic equivalents.

\section{Speaker (2)}

The speaker in this written conversation is a graduate of Faculty of Arts, Department of Islamic Archeology, and she has received her education in Arabic throughout all her educational stages. She attended an intensive course of English, and the researcher (also the addressee) happened to be her English instructor. She works as a sales representative. The conversation here was a casual/informal chat. In other words, no specific topic was discussed.

4) Me: Izayek ya 'azza?

"إزيك با عزة:"How are you, Azza?”

$\begin{array}{lllr}\text { Speaker (2): } & \text { Miss you } & \text { awy } \\ \text { V } & \text { pronoun adv } \\ & \text { "I Miss you very much" }\end{array}$

In the previous sentence, the system morpheme is in English (pronoun) and the content morpheme is Arabic (adverb); therefore, the ML is English and the EL is Arabic.

5) Me: hatkalemieny imta?

"When will you call me?"

$\begin{array}{ll}\text { Speaker (2): } & \text { Bokra, after work? } \\ & \text { Noun prep noun } \\ \text { "Tomorrow after work?" }\end{array}$

In this sentence, the system morphemes are in Arabic (determiner, preposition) and the content morphemes are in English (noun); therefore, the ML is Arabic and the EL is English. Thus, in the above mentioned two sentences, speaker (2) 
switched between English and Arabic utilizing English as the ML in one sentence and Arabic as the ML in the other one. As for the motivations, although the researcher's questions were in Arabic, the addressee chose to code-switch between English and Arabic to converge to the speaker's occupation and the relation between the speaker and the addressee as the researcher used to be her English instructor.

\section{Speaker (3)}

The speaker in this conversation is a graduate of the Faculty of Arts, English Department, and she has attended language schools in all the education stages. She is currently working as an English as a second language (ESL) instructor at the British University in Egypt. The topic discussed in the first sentence was about work, and the second sentence was about their sociolinguistics course (the speaker and addressee are colleagues at work, and they are doing post graduate studies in Linguistics, at the Faculty of Languages, Ain Shams University).

6) Me: ma Ish ma reftsharod Iky w kontnayma

معلث معرفتش أرد عليكى وكنت نابيه

"I am sorry, I couldn't pick up as I was sleeping"

$$
\begin{array}{ll}
\text { Speaker (3): } & \text { B-rahtik you don't have to justify } \\
& \text { Prep-noun-gen pr v-neg prep v } \\
\text { "It is okay, you don't have to justify" } &
\end{array}
$$

In sentence no. (6), the majority of the system morphemes are in English (pronoun, negative marker, and preposition) and the content morpheme (noun) is in Arabic; therefore, the ML is English and the EL is Arabic.

7) Me: ashofk bokra ìnshaảảllah "Will see you Tomorrow, if God wills"

$$
\begin{array}{ll}
\text { Speaker (3): } & \begin{array}{l}
\text { haty } \\
\text { imp-3msg prep-pr3msg ill-chapter } \\
\text { "Bring with you the chapter" }
\end{array}
\end{array}
$$

In this sentence, all the system morphemes are in Arabic (Determiner and prepositions) and the content morpheme is in English, so the ML is Arabic and the EL is English. Thus, after analyzing the two previous sentences, speaker (3) 
utilized English as the ML in one sentence whereas Arabic was the ML in the other one. As for the motivations that generated code switching, it can be argued that firstly, it is due to the speaker's educational background and occupation. Second, this is also because of the topic being discussed as in sentence no. (7).

\section{Speaker (4)}

The speaker in this conversation is a graduate of Faculty of I anguages, English Language Department, and she works as an administrative assistant in a bank. The speaker was a college friend to the addressee. The topic being discussed was about arranging an outing.

8) Me: 'amla īh?

"How are you doing?"

$\begin{array}{llll}\text { Speaker (4): } & \text { ảna andi } & \text { depression } & \text { rahiib } \\ & \text { Pr prep-gen noun } & \text { adj-terrible } \\ & \text { "I have a terrible depression" } & \end{array}$

In sentence no. (8), all the system morphemes are in Arabic (preposition, noun, genitive) Thus, the ML is Arabic and the EL is English due to the occurrence of the content morpheme (noun) in English. Moreover, by applying the "frequency criterion" of the MLF, the ML is Arabic and the EL is English.

9) Me:ma tygy nokhrog yom ìl-gom'a "Let's go out next Friday"

$\begin{array}{llll}\text { Speaker (4): } & \text { Friday } & \text { msh ảdra ả 'ml } & \text { haga } \\ \text { Noun } & \text { "I can't do anything on Friday" }\end{array}$

In the previous sentence and like sentence (8), the system morpheme in the sentence is in Arabic (negative marker) in addition to the dominant structure of the sentence, and the content morpheme is English, so the ML is in Arabic and the EL is English. Thus, in the previous two sentences of the conversation, speaker (4) chose to utilize Arabic as the ML and English as the EL. As for the motivation behind the speaker's code switching, it can be deduced that it is only because of the speaker's educational background. 


\section{Speaker (5)}

The speaker is a graduate of Faculty of Arts, English Department, and she is working as an English Instructor in Zweil University of Science and Technology. She used to be a colleague to the addressee at the GUC German University in Cairo, where she was working as an English Instructor. The topic being discussed was on the speaker's progress of her MA thesis at the American University in Cairo (AUC).

10) Me: åkhbar ìl-ktaba īh?

"How is your thesis writing?"

Speaker (5): $\quad \bar{\imath} l$ - thesis $\quad$ day'a

det noun adj-messed up

"The Thesis is messed up"

In sentence no. (10), the system morpheme (determiner) is in Arabic and the Content morpheme (Noun) is in English .Therefore, the ML is Arabic, and the EL is English.

$\begin{array}{lll}\text { 11): ảna 'andi } & \text { meeting } & \text { bokra } \\ \text { Pr prep-gen } & \text { noun } & \text { noun-tomorrow } \\ \text { "I have a meeting tomorrow" } & \end{array}$

In sentence no. (11), all the system morphemes are in Arabic (Pronoun, preposition), and the content morpheme is in English. Therefore the ML is Arabic, and the EL is English. Thus, in the two analyzed sentences by speaker (5), the ML is Arabic and the El is English due to the speaker's use of (content morphemes / nouns) in English, while the rest of the sentences are in Arabic. The reasons behind code switching made by speaker (5) are various. First, it is the speaker's educational background and her occupation. Second, it is her awareness of the addressee's occupation, and finally, it is the topic being discussed as in sentence no. (10).

\section{Speaker (6)}

The speaker in this conversation is a graduate of Faculty of Arts, Department of Psychology, and she had received her education in Arabic schools throughout the whole stages. She attended an intensive course of English, and the researcher 
(the addressee) happened to be her English instructor. She does not work. The topic being discussed was about reading books.

$$
\begin{aligned}
& \text { 12) Me: Inty fyn dlwảty? } \\
& \text { إنتى فين دلوفتىى"Where are you now?" } \\
& \text { Speaker (6): åna msh fy } \quad \text { Cairo } \\
& \text { Pr neg prep noun } \\
& \text { "I am not in Cairo" }
\end{aligned}
$$

In sentence no. (12), all the system morphemes are in Arabic (pronoun, negative marker, and preposition) and the content morpheme is in English (noun). Therefore, the ML is Arabic, and the EL is English.

$$
\begin{aligned}
& \text { 13) Me: Isstaryty ìl-ktab? } \\
& \text { اثتتريتى الكتاب "Did you buy the book?" } \\
& \text { Speaker (6): ìl-kitab mish fi il-bookstores } \\
& \text { det-noun neg prep det-noun } \\
& \text { "The book is not in the bookstores" }
\end{aligned}
$$

In sentence no. (13), the system morphemes are in Arabic (determiner, preposition, negative marker), and one of the content morphemes is in English (the noun "bookstores") .Therefore, the ML is Arabic, and the EL is English. Thus, in the written sentences of speaker (6), Arabic was utilized as the ML. It is clear that speaker (6) chose to switch to English, in order to converge to the addressee's occupation as she used to attend an English course with the addressee.

\section{Speaker (7)}

The speaker in this conversation is a graduate of Faculty of Pharmacy, Cairo University. She is the researcher's friend, and the Topic being discussed is about a wedding the speaker was going to attend.

14) Me: ìl-fostan lonoh ìh?

"What is the color of the dress?" 


$\begin{array}{llll}\text { Speaker (7): } & \text { Off white dakhel } & \text { ma" } & \text { champagne } \\ \text { Noun } & \text { verb } & \text { preposition noun } \\ \text { "Off white intertwined with champagne" }\end{array}$

In sentence no. (14), content morphemes are in English (nouns) and the system morpheme (prepositional verb) is in Arabic .Therefore, the ML is Arabic, and the EI, is Fnglish.

15) Me: sawwary kitīr baảa

"Take as many photos as you can"

Speaker (7): Da ảna h'ml photo session lama hroh ìl-hotel
dem pro verb noun relative pro verb det-noun
"I will have a photo session when I arrive at the hotel"

In this sentence, content morphemes are in English (nouns), and the system morphemes (demonstrative, pronoun, and determiner) are in Arabic .Therefore, the ML is Arabic, and the EL is English. Thus, in the two sentences written by speaker (7), the ML is Arabic, and the EL is English. As for the motivations that promoted code switching, it can be concluded that it was the speaker's choice of loanwords such as "off white and photo-session"

\section{Speaker (8)}

The speaker in this written conversation attended English schools, and she is a graduate of Faculty of Pharmacy, October University of Modern Sciences and Arts (MSA). She is a friend of the addressee, and the conversation was a casual conversation about a general topic.

16) Me: izayk? wahashteeny

"How are you, I miss you"

$\begin{array}{lll}\text { Speaker (8): } & 2 \quad \text { months } & \text { matklmnash } \\ & \text { Noun noun } & \text { negative verb pronoun } \\ & \text { "We have not talked for two months" }\end{array}$

In sentence no. (16), some of the content morphemes are in English such as (two, months), and the system morphemes are in Arabic (e.g. negative marker), so the speaker switched between English and Arabic using Arabic as the ML and 
English as the EL. As for the reason behind code-switching, the topic was general, and the speaker's major was not related to the English language, but may be it was her educational background in school that encouraged the codeswitching. It can also be remarked that the reason is the speaker's awareness of the addressee's occupation as an English instructor.

\section{Speaker (9)}

Speaker (9) received her education in English schools, and she is a graduate of the Faculty of Languages (Al-Alsun), Ain Shams University. She is a housewife and a mother of two children. She is currently doing her master's degree in Teaching English as a Second Language (TESOL) at the AUC.

17) Me: ảna bafakar, raảyk ìh?

"I am considering, what do you think?"

Speaker (9): I highly recommend this, $\quad \bar{\imath}$-daynamics fy $\bar{\imath}$-class hayla pro adv verb demo det. noun prep det. noun adj "I highly recommend this, the dynamics in the class are great"

In sentence no. (17), there is an inter-sentential and an intra-sentential codeswitching. While the first part of the sentence was in English, speaker (9) switched between English and Arabic. The majority of the content and system morphemes are in English, so ML is English, and EL is Arabic. Thus, speaker (9) utilized English as the ML. The topic being discussed was about an English class attended by the speaker in her TESOL program, so it can be deduced that the topic is the factor that led speaker (9) to switch between English and Arabic.

\section{Speaker (10)}

Speaker (10) received her education in Arabic schools, and she is a graduate of Faculty of Commerce, Arabic section, Cairo University. She is a housewife and a mother of four children. She has never worked before. The topic of the conversation was about dieting and losing weight.

18) Me: ha, tamnyny?

ها طنيني "So, any updates?" 


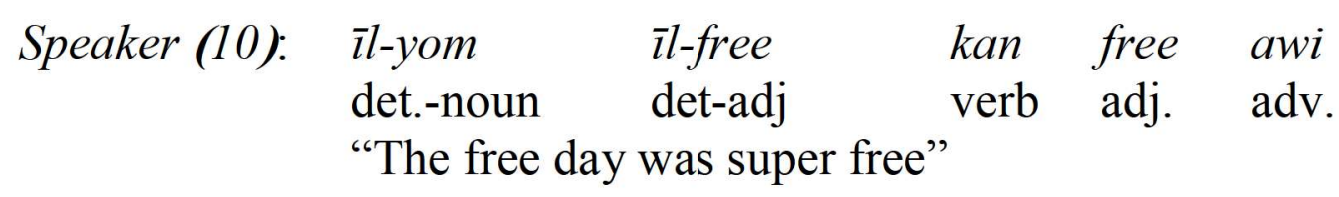

In sentence no. (18), the speaker chose only one word to be content morpheme (the adjective "free"), but the rest of the sentence is in Arabic. By applying the frequency criterion of the MIF, Arabic is the MI, and English is the FI. As for the reason that caused code switching, it may be concluded that it is the topic being discussed because "the free day in the diet" is a loanword that is used to be said in that way.

\section{Findings}

To answer the first research question which tries to explore the sociolinguistic factors and motivations behind code-switching, and after analyzing the given data, it is found that there are several factors that trigger code-switching in written instant messages. In the light of the Audience Design Theory, the first factor belongs to various social reasons, such as the addressee's occupation and educational background. In other words, speakers chose to shift their style according to their consideration of the addressee's occupation, educational background, and knowledge. Examples are found in the conversations with the addressee and speaker (1), speaker (2), and speaker (6). Speaker (1) is an old friend who is aware that the addressee is working as an English instructor, also both speaker (2) and speaker (6) were students who attended an English language course, and the addressee was their instructor. This agrees with the results of (Mostafa, 2011, 111) that proved that code-switching serves as a means of communication that functions as a communicative strategy for facilitating communication and creating solidarity with the audience.

The second factor that caused code-switching is the topic. The topic that was discussed in sentences $(1,2$, and 3$)$ by speaker (1) was about work and job interview. Moreover, sentence no.7 by speaker (3) discussed a topic about the Sociolinguistics course that the speaker and the addressee were attending in their post graduate studies. Also, sentences no.10 and 11 by speaker (5) are about discussing the speaker's progress in her MA thesis in the American University in Cairo. Additionally, speakers switched to English because the words they use are loanwords that have no other equivalent in Arabic. For instance, speaker (10) switched to English when she was speaking about (the free day in the diet). Therefore, one of the reasons is to "fill lexical gaps" as it was suggested by Bassiouny $(2009,29)$. 
Finally, it is also worth mentioning that the speaker's occupation can strongly affect the speakers' choice of languages as it happened with speaker (3) who is working as an English instructor for under graduate students in reputable universities. In addition, the educational backgrounds of the speakers play a remarkable role in code-witching as speaker (3), speaker (4), and speaker (5) studied the English language as their major.

To answer the second research question, which tries to demonstrate the structure of the sentences, the speakers opted for switching between the English language and the Arabic language making Arabic as the base language and English as the borrowed language. According to Myers-Scotton's model of matrix language, it is found that in 14 out of 18 sentences, Arabic was the matrix language (ML), and English was the embedded language (EL). When it comes to the findings of the most frequently used English words the current findings showed that Arabic speakers tend to use (nouns). While switching between Arabic and English, Arabic speakers are more likely to borrow (nouns) from the English language and embed them in their writing as it is clear in sentences $1,2,3,4,7,8,9,10,11,12$, and 13 . Additionally, the most common format used by the speakers is (Arabic "determiner"+ English "noun") such as (îl -nursery, îl work,īl-chapter...etc.).

\section{Conclusion}

In this study, the phenomenon of Arabic/English code-switching in instant messaging was analyzed within the framework of the Audience Design Theory developed by Bell in (1984) utilizing the tool of Myers-Scotton's model of matrix language (1993). Firstly, this study investigated the factors and reasons that motivate the speakers to employ code-switching while writing instant messages. Secondly, it analyzed the structure of the code-switch code-switched sentences.

In the discussion of these findings, different characteristics related to codeswitching in Arabic-English written contexts can be considered. One interpretation in the light of the audience design theory is that the speakers' shift of their style is driven by various factors. These factors can be social such as the speaker's education or occupation. They also can be audience factors such as the speaker's awareness of the addressee's knowledge, education, and interests. Finally, they can be non-audience factors such as the topic being discussed in the conversation. Speakers adjusted their speech and preferred to switch to English to converge to the audience's knowledge. This showed that the audience is the main influencer in the conversation. In other words, the addressee is the one who controls the conversation more than the speakers themselves. Speakers 
switch codes intentionally to converge to the addressee's education, occupation, knowledge, and backgrounds. Therefore, when the speakers switch codes, they switch them due to any of the previously mentioned reasons and motivations.

The second finding is that in the process of English/ Arabic code-switching, Arabic speakers tend to use Arabic as the matrix/base language while English is used as the embedded/ borrowed language. One interpretation for the use of Arabic as the matrix language and Fnglish as the embedded language is that speakers are native Arabic speakers who try to utilize English in their speech; but when they do, they switch to English using content morphemes, specifically nouns. Additionally, Arabic was the Matrix language due to being more frequent and dominant than English and due to the speakers' use of system morphemes in Arabic, specifically determiners.

As for the limitations of the study, the sample is limited; thus, it is recommended to increase the number of the participants to get generalized results. It is also would be better if there is more than one addressee to compare how speakers converge to different addressees.

Finally, it should be taken into consideration that this study is a preliminary one that analyzes interesting data for the research which is driven from instant messages. Therefore, it is essential to call for further research in this area. It is suggested to have more future research on instant messages' applications such as "WhatsApp" and "Facebook Messenger" in other linguistic areas rather than sociolinguistics. These areas can be in the field of psycholinguistics, cognitive linguistics, and corpus linguistics as they will contribute to our understanding of the speakers' psychology, ideology, cognition, and linguistic style. Finally, it needs to be highlighted that these applications represent a new, rapidly evolving type of human communication that needs to be deeply investigated.

\section{Works Cited}

Alhazmi, Albatool. 2016. "Linguistic Aspects of Arabic-English Code Switching on Facebook and Radio in Australia". International Journal of Applied Linguistics \& English Literature 5, no.3, 184-198. http://dx.doi.org/10.7575/aiac.ijalel.v.5n.3p.184

Androutsopoulos, Jannis. 2014. "Languaging When Contexts Collapse: Audience Design in Social Networking". Discourse, Context, and Media 4, no.5, 62-73.

https://www.sciencedirect.com/science/article/pii/S2211695814000257 
Bassiouny, Reem. 2009. Arabic Sociolinguistics. Edinburgh: Edinburgh University Press.

Bell, Allan. 1984. "Language Style as Audience Design." Language in Society 13, no. 2, 145-204.

----. 1991. The Language of News Media. Oxford: Blackwell.

-----. 2001. "Back in style: Reworking Audience Design". In Style and Sociolinguistic Variation, 139-69.

Chowdhry, Amit. 2016. "WhatsApp Hits 500 Million Users." Forbes, April 22, 2016.

https://www.forbes.com/sites/amitchowdhry/2014/04/22/whatsapp-hits-500million-users/\#aca9d3c702a7

Chun, Mart. 2001. "Testing the Matrix Language Model, Evidence from KoreanChinese Intra-Sentential Code Switching". Thesis, Michigan State University.

https://www.researchgate.net/publication/313218901_The_matrix_language frame model_Developments_and_responses

Dahl, Kimberly. 2009. "Audience Design and Code-Switching in Bayside, Texas". MA diss., University of Texas.

https://www.academia.edu/30921889/Audience_design_and_codeswitching_in_Bayside_Texas

Gal, Susan. 1988. "The Political Economy of Code Choice." Codes-witching: Anthropological and Sociolinguistic Perspectives 48, 245-64.

Giles, Howard and Peter Powesland. 1975. Speech Style and Social Evaluation. London: Academic Press.

Goffman, Erving. 1981. Forms of Talk. University of Pennsylvania Press, Philadelphia.

Grosjean, François. 1982. Life with Two Languages: An Introduction to Bilingualism. Cambridge: Harvard University Press.

Gumperz, John. 1982. Discourse Strategies. Vol. 1. Cambridge: Cambridge University Press.

The Library of Congress, last modified November 28, 2107, https://www.loc.gov/catdir/cpso/roman.html

Macmillan Dictionary, last modified July 6, 2014. https://www.macmillandictionary.com/dictionary/british/whatsapp

Macswan, Jeff. 2005. "Code Switching and Generative Grammar: A Critique of the MLF Model and Some Remarks on "modified minimalism". Bilingualism: Language and Cognition 8, no.1, 1-22.

https://doi.org/10.1017/S1366728904002068 
Malik, Nazir. 2016. "The Matrix Language Frame Model: An Empirical Evaluation". Sci. Int. (Lahore), 28, no.2, 2105-2112.

Meyerhoff, Miriam. 2006. Introducing Sociolinguistics. London: Routledge.

Milroy, Lesley. Observing and Analysing Natural Language: a Critical Account of Sociolinguistic Method. Oxford: Blackwell, 1987.

Mostafa, Ruba. 2011. "SMS code-switching among Teenagers in Jordan". PhD. Dissertation, Middle Fast University. https://meu.edu.jo/libraryTheses/586cbe23a5504_1.pdf

Muysken, Pieter. 2000. Bilingual Speech: A Typology of Code-mixing. 11. Cambridge: Cambridge University Press, 2000.

Myers-Scotton, Carol. 1993. Duelling Languages: Grammatical Structure in Code-Switching. New York: Oxford University Press.

Samhan, Alaa. 2017. "Social Aspects in Social Media: Code Switching and Code Mixing in Twitter." Research on Humanities and Social Sciences 7, no.18, 110-115. www.iiste.org.

Sharaf El Din, Ahmed. 2014. Sociolinguistic Study of Code-switching of the Arabic Language Speakers on Social Networking. International Journal of English Linguistics 4, no.6, 78-86. http://dx.doi.org/10.5539/ijel.v4n6p78

Wakasa, Mwandije. 2004. "The Matrix Language Frame Model of Code Switching As Applied to Kiswahili-English Code Switching in Kenya". MA dissertation. University of Nairobi.

http://erepository.uonbi.ac.ke/handle/11295/18400

Wei, Li. 1998. "The "why" and "how" Questions in the Analysis of Conversational Code-switching". Code switching in conversation. Language interaction and identity. London: Routledge, 156-76. 


\section{Appendix}

The transliteration scheme used in this paper is the Transliteration Scheme for Non-Roman Scripts, which is approved by the Library of Congress and the American Library Association.

\begin{tabular}{|c|c|}
\hline 1 & $\mathbf{A}$ \\
\hline ب ب & B \\
\hline$ت$ & $T$ \\
\hline ث & Th \\
\hline T & $\mathrm{J}(\mathrm{MSA}) / \mathrm{g}$ (ECA) \\
\hline$\tau$ & h \\
\hline$\dot{\bar{z}}$ & Kh \\
\hline s & D \\
\hline$\dot{j}$ & Th \\
\hline $\mathrm{j}$ & $\mathbf{R}$ \\
\hline$j$ & $\mathbf{Z}$ \\
\hline س - l l l & $\mathbf{S}$ \\
\hline ش ش & Sh \\
\hline ص & $\mathbf{s}$ \\
\hline 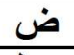 & d \\
\hline$b$ & $t$ \\
\hline ظ & $\mathbf{z}$ \\
\hline$\varepsilon$ & $\frac{6}{6}$ \\
\hline$\dot{\varepsilon}$ & Gh \\
\hline فن & $\mathbf{F}$ \\
\hline ق & $\mathbf{Q}$ \\
\hline ك & $\mathbf{K}$ \\
\hline$J$ & $\mathbf{L}$ \\
\hline 3 & $\mathbf{M}$ \\
\hline ن & $\mathbf{N}$ \\
\hline$\Delta$ & $\mathbf{H}$ \\
\hline 9 & $\mathbf{W}$ \\
\hline s & $\mathbf{Y}$ \\
\hline i & $\vec{a}$ \\
\hline$!$ & $\overline{\mathbf{I}}$ \\
\hline
\end{tabular}

